\title{
TERROR NARRATIVE: REPRESENTING STATE VIOLENCE IN MODERN INDONESIAN LITERATURE
}

\section{Ferdinal $^{*}$}

Department of English, Faculty of Humanities, Andalas University, Padang 25163, Indonesia

\section{ARTICLE INFO}

Keywords:

Terror

Narrative

State violence

Modern Indonesian

literature

Article History:

Received: $29 / 12 / 2020$

Accepted: 15/10/2021

Available Online:

$18 / 11 / 2021$

\begin{abstract}
A B S T RA C T
Literature and society are a way of looking at problems in society. Literature not only functions as entertainment, but it may also represent socio-political problems. Some literary works even carry more roles as both a reflection of such issues and a means of protest against them, including human rights violations. This paper examines how Indonesian literature has reflected human rights breaches, such as oppression in Indonesia during the New Order era. This qualitative research was conducted through direct documentation. The research revealed that the regime punished any individuals, groups, or institutions which tried to challenge its policy by the name of national stability. Some writers, such as Putu Wijaya, used anecdotes to protest against such oppression. He was a prolific Indonesian writer whose works often expose socio-political issues, such as human rights violations in Indonesia. His writings suggest his disagreement with such abuses. The three short stories investigated here "Sket," "Mulut," and "Rakyat" represent Putu Wijaya's dissent with the violence performed by the apparatus of the regime. Playing his role as a literary activist, Putu uses these stories to remind rights perpetrators that such cases as seen in the stories have taken place and might take place somewhere in Indonesia.
\end{abstract}

2442-305X / (C) 2021 The Author, this is open access article under the (CC-BY-NC) license (https://creativecommons.org/licenses/by-nc/4.0/), DOI:10.19105/ojbs.v15i2.4113

\footnotetext{
$\overline{\text { * Corresponding Author: }}$

Email address: ferdina109@gmail.com (Ferdinal)
}

\section{A. Introduction}

This article examines three works by Indonesian surrealist writer Putu Wijaya on human rights-related topics. The paper explores Putu Wijaya's short stories representing psychological and sociopolitical terror by looking at how he depicts terror in his stories and how they greet the New Order regime that conditioned them. The three stories revisited in this paper are "Sket"1 (Sketch), "Mulut"2 (Mouth), and "Rakyat"3 (People). These stories deliver Putu Wijaya's critique and attention to humanistic

\footnotetext{
${ }^{1}$ Putu Wijaya, "Sket," in Kado Istimewa: Cerpen Pilihan Kompas 1992, ed. Kenedi Nurhan (Jakarta: Harian Kompas, 1992), 70-79.

2 Putu Wijaya, "Mulut," Horison: Majalah Sastra, October 1995, 45-49.

${ }^{3}$ Putu Wijaya, "Rakyat," Horison: Majalah Sastra, October 1995, 56-57.
} 
matters in a certain period of circumstances.

The works exhibit creative ability that regrets the deplorable conditions and results of the nation's physical and typical application. The works showcase imagination that deplores the unwanted situations and consequences of the government's bodily and typical moves on Indonesia's community members. These stories resist Indonesian socio-political problems along the last few years of the New Order fiction that could be understood as ways to enable the works to face the nation-state terror. In place of fracturing the stories, depictions of violence, frightening stories, and the bodily and emotional suffering of the characters all contribute to the exploration of the history of national terrorism.

Jameson argues that the creation of a literary work cannot be separated from its sociopolitical referent. Therefore, it helps examine terror in the New Order literature by understanding it from the era's political perspective. Describing this context, Collins claims, "The New Order portrayed itself as a guardian of order and security against immoral and anarchist forces. ${ }^{4}$ The impact on the people in the name of security tried to protect the order of the forgotten country. Authorities argued that persons, as well as groups, must comply with the schemes they enforced.

As a consequence, the country has used a variety of violent forms to

\footnotetext{
${ }^{4}$ Elizabeth Fuller Collins, "Indonesia: A Violent Culture?," Asian Survey 42, no. 4 (2002): 582-604, https://doi.org/10.1525/as.2002.42.4.582.
}

approach its aims. Simultaneously, persons and groups commit violence and make use of the condition for their advantage. The repeated violent acts, including state-designed brutality, as a consequence of the government's policies alongside its practices, are based on the notion of terrorism, not on the narrative of injustice that partly controls the mind of the Indonesian people. Acts of terrorism increase to common incidents. These events are considered responses to protesting real or hypothetical horrors. The national organization seeks to make the people irreversible passive sufferers. Collins further claims that "the Suharto administration has institutionalized national terrorism by taking the mark of the opposition as a "communist" and using demonstrators and separatist troops and paramilitary forces when needed." ${ }^{5}$

Terror has been one of the essential focuses of contemporary Indonesian writing. Some scholars have studied the issues of terror in Indonesian literature. For example, lyubenu claims that Indonesian postcolonial literature, which represents terror, is characterized by some themes: confrontation, captivity, and oppression. These traits indicate the immediate connection with social phenomena in society. The writers of short fiction who are attentive to such themes try to represent and reconstruct them in fictional works. ${ }^{6}$ Writers such as Motinggo Busye, Danarto, Seno Gumira Ajidarma, and Agus Noor fit such criteria.

\footnotetext{
${ }^{5}$ Collins, 583.

${ }^{6}$ Edi AH lyubenu, "Estetika Teror (Khas) Cerpen Koran," Surabaya Post, June 12, 2000.
} 
Next, Astuti looks at the issue of poverty in Putu Wijaya's stories. ${ }^{7}$ Then, in line with lyubenu, Ferdinal investigates the issues of state violence (state terror) in the works of Seno, ${ }^{8}$ injustice in A. A. Navis's stories, ${ }^{9}$ and the rights of women in the stories of The Jakarta Post. ${ }^{10}$ Herlambang researches a broader scope of cultural violence post-Indonesian New Order. ${ }^{11}$ Specifically, Heryanto studies the representation of Indonesian lives after the New Order in screen culture. ${ }^{12}$ Wahyuni seeks censorship in journalism and truth in literature, ${ }^{13}$ while Heriyati et al. concentrate their research on trauma in Indonesian literary works. ${ }^{14}$ Last, Nurhadi

7 Tri Sakti Murti Astuti, "Aspek Sosial dalam Kumpulan Cerpen Protes Karya Putu Wijaya: Tinjauan Sosiologi Sastra" (Bachelor Thesis, Universitas Muhammadiyah Surakarta, 2010).

8 Ferdinal, "Censorship, Resistance and Transformation in Modern Indonesian Literature," Mediterranean Journal of Social Sciences 4, no. 1 (2013): 269-72, https://doi.org/10.5901/mjss.2013.v4n1p269.

9 Ferdinal, "Injustice: Revealing Human Rights Issues in Ali Akbar Navis's Short Fiction," European Journal of Interdisciplinary Studies 1, no. 1 (2015): 137-43, https://doi.org/10.26417/ejis.v1i1.p137143.

${ }^{10}$ Ferdinal, "Women's Rights and Colonization in the Short Story of the Jakarta Post," Vivid: Journal of Language and Literature 9, no. 1 (2020): 1-11, https://doi.org/10.25077/vj.9.1.1-11.2020.

${ }^{11}$ Wijaya Herlambang, Kekerasan Budaya Pasca 1965: Bagaimana Orde Baru Melegitimasi AntiKomunisme Melalui Sastra dan Film (Tangerang: Marjin Kiri, 2013), 310.

${ }^{12}$ Ariel Heryanto, Identitas dan Kenikmatan: Politik Budaya Layar Indonesia, 2nd ed. (Jakarta: Kepustakaan Populer Gramedia, 2018).

13 Dessy Wahyuni, "Pertarungan Jurnalisme dan Sastra Dalam Menguak Kebenaran," Paradigma: Jurnal Kajian Budaya 9, no. 3 (2019): 231-55, https://doi.org/10.17510/paradigma.v9i3.325.

14 Nungki Heriyati, Riris K. Sarumpaet, and Christina T. Suprihatin, "Speaking Through Silence: Trauma in Literary Work," in Proceedings of the International Conference on Business, Economic, asserts that violence (terror) after Indonesian independence has energized some writers to represent such a theme artistically. ${ }^{15} \mathrm{He}$ lists some concerns, like the PKI issues in Ahmad Tohari's Kubah (Dome, 1980), Ronggeng Dukuh Paruk (1982), Lintang Kemukus Dini Hari (A Shooting Star at Dawn, 1985); and Umar Kayam's Sri Sumarah (1986) and Para Priyayi (1992).

We can include more writings to the list, first, the colonial terror and old tradition in Pramoedya Ananta Toer's Perburuan (The Fugitive, 1950) and state terror in Nyanyi Sunyi Seorang Bisu (The Mute Soliloquy) (I and II, respectively 1995 and 1997), and Gadis Pantai (The Girl from the Coast, 1982), second, the PKI case in Umar Kayam's Bawuk (1975), and last, Ajip Rosidi's Anak Tanah Air (Child of the Home Land, 1985). These stories center on terror-related issues to represent the socio-political problems in Indonesia. These authors attempted to fight against those in power by publishing works that portray the terrible repression put in place upon the people through a fictional lens. Although many people argue about the accuracy of literature, others have fulfilled their needs to understand Indonesian history through fictional representations.

\footnotetext{
Social Science, and Humanities - Humanities and Social Sciences Track (ICOBEST-HSS 2019) (Bandung, Indonesia: Atlantis Press, 2020), https://doi.org/10.2991/assehr.k.200108.037.

${ }^{15}$ Nurhadi, "Kekerasan di Indonesia dalam Karya Sastra," Ibda': Jurnal Kajian Islam dan Budaya, no. 55 (2009): 1-11.
} 


\section{B. Method}

This study seeks to investigate the depiction of state violence in three media stories, "Sket," "Mulut," and "Rakyat" by Putu Wijaya. This qualitative research was conducted through direct documentation, primarily from the three stories and supplementarily from other sources. The research data dealt with how the stories represent state violence in Indonesia. Several pieces of information or other elements such as symbols and metaphors became central to this research. The concept of oppression in postcolonial criticism became a reference in studying state violence in Kompas' media narrative.

In this article, the analysis dealt with three areas of critical aspects. Initially, I analyzed human rights' contents in the works because they were written with the socio-political portrayal of human rights violations. Next, I believe that Putu Wijaya protests against the Indonesian nation state's treatment of its people's freedom of expression and right to life. Here I showed how Putu Wijaya presents terrorized figures fictionally and socio-politically criticizes the state apparatus's aberrant behaviors. Lastly, I examined the rights perpetrators. I believe that Putu Wijaya writes terrorized characters in his stories as a way to blame the perpetrators, either lay people or state agencies. Before beginning my analysis of Putu Wijaya's stories, I would like to contextualize fiction in the academic debate on terror representation.

\section{Results}

\section{Putu Wijaya: Terror and Justice}

Putu Wijaya's works respond to terror, which portrays the friction between terror and justice in fictional appeal. Historically, Putu was among the first Indonesian writers who introduced such themes to his readers. In delivering his message of terror, Putu relies on the settings as his important aspect to present his messages. Being a short fiction specialist, Putu is interesting to study because of some reasons. First, as a socio-political writer, he selects some of Indonesia's most stressful social issues through which he mixes the aesthetic and the political stuff. Next, he is the one who creates a novel way of composing on terror. Last, his stories consist of romance which embraces acts of violence and oppression.

Putu Wijaya is not known as a subversive author. He has never been a direct target of the Indonesian government system. However, witnessing all Indonesian governments after independence, he has been preoccupied with such different governments' practices. Avoiding the portrayal of particular national happenings, he addresses socio-political problems around him and draws them into his narratives. Are such recordings evident in his works, such as Apakah Kita Sudah Merdeka (Are We Free Yet?), Aduh (Ouch), and Setan (Devil)? Although Putu might not be as responsive as his senior W. S. Rendra, who was vocal to the state, his critical expression moved through his works, both 
writing and drama. In light of theatre, many recognize Putu Wijaya as a writer who conveys something through theatre to skip censorship and avoid anger and hatred.

Putu exercises his literary skills in representing violent acts. Maier calls it "the central theme of Putu Wijaya's literary work ... that keeps on breaking the rules of expectation, the law of genre." 16 According to Rafferty, Putu Wijaya's fiction is "organized to deceive and disturb the reader, to encourage them to question accepted norms. ${ }^{17}$ Putu Wijaya looks at a trivial happening, which he deconstructs into an impressive delivery. Dewanto says that Putu Wijaya's stories remind the readers that criminal deception, brutality, and oppression can be performed by anyone no matter who they are and what social class they are from. ${ }^{18}$

Critics believe that Putu Wijaya demonstrates his appeal for social values by his imagination. Astuti argues that Putu Wijaya, in his fiction, attempts to uncover the unequal gaps which occur in society. The inequalities might be poverty, arbitrary behaviors of the authority, and social inequalities. ${ }^{19}$

\footnotetext{
${ }^{16}$ Henk M. J. Maier, "Telling Tales, Cutting Throats the Guts of Putu Wijaya," in Roots of Violence in Indonesia, ed. Freek Colombijn and J. Thomas Cinblad (Leiden: KITLV Press, 2020), 66.

17 Ellen Rafferty, "The New Tradition of Putu Wijaya," Indonesia 49 (1990): 103-16, https://doi.org/10.2307/3351055.

18 Nirwan Dewanto, "Penutup," in Kado Istimewa Cerpen Pilihan Kompas, ed. Kenedi Nurhan (Jakarta: Harian Kompas, 1992), 143-49.

${ }^{19}$ Astuti, "Aspek Sosial dalam Kumpulan Cerpen Protes Karya Putu Wijaya: Tinjauan Sosiologi Sastra," 3.
}

Putu Wijaya's literary creativity should not be read just as a record of what has happened. It performs his effort to arouse his readers to struggle against wrongdoings in their society. He finds his effective method to convey messages to his readers by portraying terror. Many literary practitioners and scholars believe that Putu Wijaya's concepts of the fictional world are centered upon "mental terror," which, according to Sunarti, is desertion, betrayal, a crime against logic, but true. Terror should not be harsh; it might rustle or be wholely colorless. ${ }^{20}$

Although the terror he depicts in his work is mainly mental suffering, I believe he despises any act that violates the rights of others. He raises his voice against the violent actors, whether they be persons, groups, or government agencies. $\mathrm{He}$ is interested in defending the rights of the people on the margins of society: the impoverished, the weak, the neglected, and the impotent. His interest is not with the have, but the have-not, who get duped by the government hands at the low government hierarchy, such as Lurah (the village chief who is in charge of a local authority). His settings are generally people's lives at the levels of $R T$ (Rukun Tetanga), ${ }^{21} R W$ (Rukun Warga), ${ }^{22}$ or village with their activities.

\footnotetext{
${ }^{20}$ Sunarti, "Nilai Nilai Budaya dalam Novel Tiba Tiba Malam Karya Putu Wijaya: Tinjauan Semiotik" (Bachelor Thesis, Universitas Muhammadiyah Surakarta, 2008), http://eprints.ums.ac.id/id/eprint/2357.

21 Rukun Tetangga (RT) is an informal security organization of a local community in Indonesia. It exists especially in cities and suburbs, and the state widely supports its appearance, see Martha Gay Logsdon, "Neighborhood Organization in Jakarta,"
} 


\section{Putu Wijaya Plots Terror to Resist}

State violence is shown as basic in all three stories studied, underpinning the law and power. State sovereignty is elevated above violence, which derives its force from its performative power to cause bodily and emotional harm. Putu Wijaya strongly represents state sovereignty through its practice of violent acts, whether directly or indirectly, through the battle between the poor and the rich, the weak and the mighty, and leaders and their people. Putu Wijaya remains a symbolic figure who battles for state terror and symbolic violence perpetrated against the general public. Such terror and violence arrive at the level where people's rights are threatened and denied.

The stories under study have a common theme: the Indonesian government's bodily and metaphorical acts of violence perpetrated by its officers. This state-sanctioned "horror" can take numerous forms, encompassing themes like street courts and tyranny, incarceration and forced operations, and the termination of unpaid community leaders. Putu Wijaya offers a framework of human rights representation through the social settings of terror imposed by the powerful over the weak people and government apparatus. The plot and characters are based on actual events to raise public awareness about human rights breaches. There are certain rights

Indonesia $18 \quad$ (1974): $53-70$,
https://doi.org/10.2307/3350693.

${ }^{22}$ Rukun Warga (RW) is another local organization within an area of some RTs (Smallest nongovernment authority), see Logsdon. 53-70, abuses and physical and psychological traumas depicted in the stories. Putu Wijaya portrays significant events, which he refers to as anecdotes, in his stories to deliver mental terror. Putu Wijaya makes use of such stories to depict violence and oppression.

Violence in Putu Wijaya's media fiction appears as state-related terrors that pervade each community he depicts. His representations of the terror in the text allegorically allude to representing the practice of state oppression. He uses allegories to resound the nation's sociopolitical acts of violence that immediately or symbolically terrorizes its community. ${ }^{23}$ His illustrations of physical damage, mental disintegration, and moral stories of consistent variation from his central anecdotal strategy and the space in which the characters in his stories appear their significance.

From all sorts of state savagery to the refusal of the right and, at last, to the mental assault on individuals, each sociopolitical layer of the stories speaks to issues risky to Indonesian people's rights. It portrays the broken society through systematic and structural violence, both physical and symbolic shapes, and limits Putu Wijaya's pictured society's lives. From these fractured society contexts, Putu Wijaya navigates his characters to carry his cultural resistance and get it reflected in his readers' point of view towards the state. For him, they need to

\footnotetext{
23 Angus Fletcher, Allegory: The Theory of Symbolic Mode (Ithaca and London: Cornell University Press, 1964), 2.
} 
associate with the fictional actors and respond to the cases.

Putu Wijaya deals with a terrorized agency in the three stories where its picture is seen in marginalized agents' sketch. The presence of a poor boy in "Sket," victimized neighborhood leaders in "Rakyat" and an abnormal lady in "Mulut" draw the marginality of the weaker agency. Putu presents all his repressed figures as those knocked down by those having hegemony directly or indirectly legalized by the government. They are representatives of the people whose rights have been negated by persons, groups, or the government. In these narratives, Putu Wijaya draws three kinds of terror: intimidation, bureaucratic practice, and the disappearance of freedom.

\section{a. Intimidation in "Sket"}

In "Sket," Putu Wijaya depicts an impoverished boy mistaken by a wealthy family because he beats their boy. The poor boy is tormented by the Hansip. The poor villagers stand for the poor boy, and they damage the wealthy family's house. Allegorically, the work exposes the space between the have and the have-not. The work's overriding theme copes with repression performed by the have over the have-not. This story fictionalizes violent acts through a financial and physical caricature of the rich's domination over the impoverished and powerful over the powerless. $\mathrm{He}$ represents a scene of a community's activities where repression is instigated and caused by money's influence. The rich people impose their will through their control of money over the impoverished ones while the low personnel undergoes authority through destitution, scaring, and one class's stereotyping over another.

Through "Sket," Putu Wijaya argues that the government should be responsible for the big gap between the two groups. The social space encourages the have to apply their financial state over the have-not and provokes chances to react violently. This story provides a time tunnel for Indonesian people to look at the Indonesian colonial period. The colonizers performed violent acts against Indonesians for doing things the colonizers considered wrong. It occurred because the colonizers and the powerful own the law. The story portrays that nowadays, the poor without financial power are susceptible to various experiences of violence where the influential people wronged them for what they should not be responsible for.

Putu Wijaya presents the big gap between the rich and the poor. Both groups' violent acts suggest that the story works to fulfill readers' emotional wills and aim at particular political objectives. The story exposes a clash between Tony, a wealthy family boy, and Udin, a needy boy who plays and fights each other. Tony's family calls the community's apparatus Hansip to "make the law" work. Despite the simplicity of its plot, the story's objective has gone beyond it. The story suggests that the state fails to exercise fairness for the people before the law. The law cannot protect every person's rights because rights are only the property of the strong (the rich). Putu Wijaya suggests 
that financial status is capable of making the have repressed the have-not. His money-related phrases such as pay and sponsor our Hansip's uniform are evident. This financial power enables the rich to decide which oppressive acts they can apply against others. Such actions can generate other similar acts to take place, including mass destruction.

As a whole, in the story, there are few violent acts conducted by different parties, including one child over another child, the have over the have-not, and even the impoverished group over the opposite group. The first one is a depiction of violence among the children. The story represents Putu Wijaya's concern about children's lives in a diverse community where the rich and the poor people meet. Although he depicts that children recognize only fun, the two classes' mingling is like the sky and the ditch and can produce unfairness. Yet, this scene is foundational in telling Putu Wijaya's choice in approaching injustice.

Secondly, Putu Wijaya suggests that it is almost impossible to enjoy peace between the two worlds within equality. Trivial things can cause serious acts, such as rights violations, to happen. For example, when playing with Udin, by accident, Tony has his head banged on an iron fence which causes him to bleed. Tony's parents, using the Hansip, violates the rights of Udin. This scene represents structural violence performed by the community's apparatus against the weak (the poor). The Hansip has become the right hand of the powerful. Through this institution, they exercise their violence from which the weak people become vulnerable to rights violations. The apparatus tends to protect the have and negate the have-not. Putu Wijaya takes pity on the apparatus's reaction in handling the case. He shows how different treatments apply to other social classes. The rich should be given better treatment while the poor are wrong. The rich are identical to the protection and the poor to torment. Putu Wijaya's use of the words: "dibekuk, dibentak, diseret, ditarik, dipermak" (arrested, snapped, dragged, pulled into, and tortured) accompanies the scene of Udin's being treated like a convict.

The third is the anarchy performed by Udin's sympathizers. Here, Putu Wijaya represents the failure of equality before the law, which the state fails to execute. Such failure causes the weak to translate justice in their own verdict by putting in the "street law," the weaker community's immediate reaction against a specific occurrence.

Putu Wijaya passionately gives the poor people a voice to struggle against the mistreatment their group gets from the have and shows society's inappropriate reaction. The community agent's decision to defend the rich energizes the weak to struggle back. The poor sympathize with their group members, whose rights invaded. Putu Wijaya derisively criticizes the state by writing, "Ini bukan hutanrimba" (It isn't the jungle), which refers to "the law of the jungle, "denoting community apparatus's autocratic and undeserved behaviors." 
Putu Wijaya does not record the exact places. Instead, he speaks with "the Jakarta dialect" through the words such as Ihu (you), elhu (you), gebukin (hit), and gelo (mad). He portrays the poor people's sense of repression. At the same time, he indicates that "street law" is a possible answer to an argument between the poor and the opposite group. Instead of exercising their wills through community's agents, the impoverished, through their intention to "tegakkan kewarasan" (stand for righteousness), channel their anger through their street law. Being triggered by feelings and intuition, they express their anguish inhumanly. Putu Wijaya writes that:

"Kamu yang harus digebuk! Ayo hantam lagi!" "Serbu!" Batu dan kotoran makin gencar terlempar. Dalam sekejap rumah orang kaya itu rusak berat." ${ }^{24}$

(You are the one who should be beaten! Come on, hit more!" "Attack!" They throw stones and dirt. In seconds, the house of the wealthy one becomes damaged).

Voicing the hatred, anger, and hostility of the have-not over the have, Putu Wijaya suggests that the impoverished and the have may perform illogical acts when dealing with social jealousy. Both groups tend to respond reactively, so they do not think but are emotionally possessed. The law belongs to anybody whose life is disturbed, no matter who the person might be. Putu uses the Nazis to call the perpetrators.

${ }^{24}$ Wijaya, "Sket," 73-74.
In brief, Putu Wijaya chooses to show a discrepancy between the have and the have-not where they two cannot live together in one area. Their life in one community tends to encourage one group to violate the rights of another. Putu Wijaya appeals to his fans that anyone should not choose acts of violence as the right ways to solve a problem. Violence may take place anywhere, anytime, and by anybody, not always the ones with a certain power. As the work indicates, the impoverished, the have, the society's apparatus, and even the masses can become the perpetrators.

\section{b. Bureaucratic Practice in "Rakyat"}

The story of "Rakyat" appears realistic and ironic. The story tells of a few RW leaders whom Lurah has fired because they support their community members by ignoring the wills of the Lurah. Putu Wijaya concerns with the irony represented through the conception of democracy. Although satire is a commonplace phenomenon everywhere, the mockery Putu Wijaya presents is striking. It involves emotion, suspense, and sympathy for the victim. The story triggers readers' psyches to take pity on the victims. It presents an event against people's common sense and logic. People face issues of antagonism, contest, and rebuttal, which cause them to feel terrorized. The feeling of terror presents a good motive materially conquered by wrongdoing, the majority by persons, and common sense by an unreasonable plan.

This story that depicts Indonesia's social situation is an objection towards the 
New Order's bureaucratic policy. It can indicate the Indonesian government's broad practice of tight political bureaucracy. By presenting the dispute between the RW people and their Lurah, Putu Wijaya takes readers to the case of bureaucratic practice during the New Order, where lower officers have to meet the wills and abide by rules made by those who have to legalize them. Those in a lower rank are not supposed to get away from the guidelines, although they work for the good of the people they offer service.

Putu Wijaya's objection begins with the presentation of opposition. This selected idea saved him from common disagreement with the nation-state. The story's ironic line starts when the Lurah tries to confront the guardians for not going after Lurah's instructions:

"Lalu Pak Lurah memanggil mereka untuk diberi pengarahan, karena mereka dianggap sudah bertindak sendiri bahkan menentang kebijakankebijakan kelurahan." ${ }^{25}$

(The Lurah calls them for similar guidance due to the fact they were speculated to have acted on their very own and deviated from the authority's policies).

The general public caretakers, defined as excellent public organizers, no longer meet the Lurah authorities' expectations in their acts. This part reminds the authority's officials of their irrational utility of impenetrable paperwork. This act justifies the authoritarian rulers who quieten any ideas or deeds out of the

${ }^{25}$ Wijaya, "Rakyat," 56. governmental circles. This principle act of the government officer offers Putu Wijaya a literary way to remind the authorities that their officer has issued an incorrect paperwork concept, terrorizing the humans. The officer prioritizes oppressive governmental techniques over excellent humanitarian acts. Here, Putu Wijaya attempts to question the officers' acts of imposing illogical reasons above logic. He writes,

"Masyarakat ramai bingung. Kami semua bertanya-tanya, karena perbuatan baik kok malah dipersoalkan. Apa sebenarnya rencana kelurahan? Kami resah." ${ }^{26}$

(The public are confused. We keep asking because good deeds are being doubted. What is behind Lurah's plan? We are psychologically restless).

The harassment continued when Lurah fired RW's tutors and appointed new ones. Lurah's actions make people feel constant terror because they are not satisfied with the action:

"Kami ... meminta dan akhirnya menghimbau, agar pengurus RW yang kami cinta itu tidak dipecat. Karena kami senang dengan apa yang sudah dikerjakannya."

(We ... beg and finally appeal that our respected $R W$ caretakers not be fired because we are happy with their work performance).

The residents' exertion to have the pioneers restored in their open positions echoes the contention of Žižek, who calls subjective violence "a violence performed

\footnotetext{
${ }^{26}$ Wijaya, 56.

${ }^{27}$ Wijaya, "Rakyat," 57.
} 
by an identifiable agent." ${ }^{28}$ Žižek claims that subjective violence consists of two: "symbolic violence embodied in language and its forms" ${ }^{29}$ and systemic violence, "the often catastrophic consequences of the smooth functioning of our economic and political system." 30 The inhabitants' actions do not compare with Lurah's reaction. The case reminds us of an ancient joke re-narrated by Žižek:

There is an old joke about a husband who returns home earlier than usual from work and finds his wife in bed with another man. The surprised wife exclaims: "Why have you come back early?" The husband furiously snaps back: "What are you doing in bed with another man?" The wife calmly replies: "I asked you a question first-don't try to squeeze out of it by changing the topic!". ${ }^{31}$

The same activity applies to the viciousness executed by the Lurah, who, as an agent of the nation, ought to make each exertion realize the state rules inside the system of helping the individuals to realize a wished life. Differently, he decides something different. Instead of forgiving the caretakers, he punishes them. He changes his reasons from the subject of a great deed to the law of bureaucracy. He is assumed to halt savagery against the individuals. However, he commits systemic viciousness by the name of rules.

The moment incongruity shows up when the public faces the expelled

28 Slavoj Žižek, Violence (New York: Picador, 2008), 1.

29 Žižek, 1.

30 Žižek, 1.

31 Žižek, 11. caretakers (pioneers) to encourage them to fight the Lurah. Even though all inhabitants support them, the caretakers do not need to disobey the law. They agree that everybody ought to stand by this law no matter who the individual is.

"Mau hidup teratur dengan aturanaturan yang jelas dimasa depan, atau melanggar segala aturan yang kita buat sendiri, dengan mengatasnamakan kelayakan dan kebahagiaan bersama." 32

(We want to live in order with definite rules in the future or disobey the ones we make in the name of public properness and happiness).

Putu Wijaya speaks to a circumstance where deliberateness and debatable matters are differentiated from each other. The government shows up as an organization based on efficiency but acting based on the transaction. The government campaigns to advance equity but deliver a terrible form of practice to the individuals. Satirically, the story displays the caretakers do not challenge the Lurah's decision. They noiselessly stand up to such injustice:

"Kami justru melawan. Karena kami telah melakukan apa yang baik untuk warga semua, bukan hanya baik untuk Pak Lurah." ${ }^{33}$

(We do fight. Because we have performed the right one for all residents, not only what the Lurah expects).

The previous pioneers concur to their expulsion to support the culture of deliberateness. They verifiably work out

\footnotetext{
${ }^{32}$ Wijaya, "Rakyat," 57.

${ }^{33}$ Wijaya, 57.
} 
the culture to guarantee that everybody, counting the state device, abide by the law.

“... dikemudian hari tidak hanya wakil rakyat yang tidak memenuhi aturan karena tidak menyuarakan kepentingan Pak Lurah - yang dipecat, tetapi juga semua wakil rakyat yang tidak mampu menyuarakan kepentingan rakyat termasuk Pak Lurah sendiri - harus dipecat." ${ }^{34}$

(... in the future, not only public servicemen who don't take after the rules- since they don't voice the Lurah's will - are let go, but moreover, all authorities who might not represent people's need - including the Lurah himself-ought to be terminated).

The pioneers recommend that everybody ought to be break-even before the law, no matter who the person is. Once a plan is agreed upon, it must apply to everyone. Putu Wijaya contends that all pioneers must perform their work for the people's advantage.

\section{c. The End of Freedom in "Mulut"}

The story "Mulut" details a mouthless lady who an officer catches. Then, she is persuaded to make a mouth. After having one, she talks too much, and at last, she again has her lips sewn together. The story presents Putu Wijaya's endeavor to speak about one's right to life denied and executed. By explaining the mouthless lady, Putu Wijaya uncovers suffering and injustice. Employing a surrealist strategy, he suggests that something is off-base. He artistically protests any practice which

\footnotetext{
${ }^{34}$ Wijaya, 57.
}

damages an individual's rights. In uncovering such savage persecution, he wants his readers to realize the impacts of such dread and, at the same time, points to induce his victim to oppose this idea. In this story, Putu Wijaya does not try to scare his readers but make them think of such rights infringement.

Putu Wijaya writes the organization of this story by using the characterization of an anonymous lady who endures all her life beneath the nearness of bad form; the story direction of savagery beats her down. She stands between great and fiendish, likes and detests, and voiceless and vocal. She appears to be an undetermined character to voice resistance. One imperative that represents this dubious opposition may be a biological and social variation from the norm. The dissent of freedom of expression and right to life as formed and confined by her bodily imperfection: "tuna mulut" (mouthless) and how social inclusion: her status between "suka atau tidak" (like or not) by the society is clear to the lady and her nearness among her society. Injustice starts when the community opposes this idea with the irregular lady recognized by the state, which asks its agent to handle her anomaly. Through this agent, Putu Wijaya delineates the violence which comes upon the lady. He composes:

"Tiba-tiba saja bagaikan tabrakan mendadak, petugas itu membunyikan peluit dan menyerukan bahaya. Tangkap, serunya memberikan instruksi. "Tangkap, tangkap, tangkap cepat". Rumah wanita itu dikepung. 
Lalu wanita itu ditarik keluar dari rumah, untuk diamankan. "Mana mulut kamu!" teriak petugas itu dengan nafas kembang kempis. Dadanya Nampak turun-naik sehingga kami seperti mendengar suara gemelutuk. "Mana mulut kamu!" wanita yang tak bermulut itu tercengang." ${ }^{35}$

(All of a sudden, it is like a sudden collision, and the officer blows his shriek and calls "danger." Arrest," he gives instruction. "Catch, capture, capture quickly." The woman's house is encompassed. She is at that point pulled out of the house, captured. "Where's your mouth!" yells the officer with hurrying breath. His chest hurls, so we appear to listen to a black-out voice. "Where's your mouth!" the mouthless lady looks astounded).

Putu Wijaya concisely presents the violence of a government device in taking care of an individual suspected of showing up diverse and imperiling social agreement. Through the capture, which takes after detainment and crossexamination of a world fear monger, Putu Wijaya recommends a frame of opposition. The act embodies the nation capture that had happened in Indonesia amid the unused arrangement. He makes the mouthless lady convey his opposition towards such activities. The officer's response, his information to require the lady to go out of her house, and his interrogations sum to the method of detainment.

Putu Wijaya represents a detention case sample with its motives and how the act works. He depicts security behind the action and how such a problem instills in its apparatus's mind and behaviors. Consider the following:

"Kenapa dan bagaimana ia tak punya mulut. Apa maksudnya? Dan yang lebih penting dari semua itu, dari mana asalnya dan siapa yang sudah mengatur sampai semua warga terkesima sehingga menerima begitu saja kehadirannya tanpa mampu mempersoalkan, kenapa ia tidak punya mulut."

(Why and how she has no mouth. What does she mean? And overall, where she comes from and sets up all this so that all inhabitants eagerly acknowledge her nearness without addressing why she does not have a mouth). ${ }^{36}$

Putu Wijaya demonstrates that it is the security issue that concerns the administration. Anybody who torments should be "amanken" (assuaged), the administration term for detainment. So anybody who shows up distinctive will be distrusted and assured, although the person does not think so. He writes about a case by showing a battle between the individual and the officer. He writes:

"Seluruh warga keberatan dengan keputusan itu. Kami menganggap wanita itu tidak bersalah, kenapa mesti diamankan. Kenapa orang tidak punya mulut dianggap bersalah?"37

(All individuals protest to the choice. We expect she is guiltless; why ought to she be secured. Why ought to individuals who have no mouth be found guilty?).

The inhabitants address the rationale behind the woman's capture.

\footnotetext{
${ }^{36}$ Wijaya, "Mulut," 47

${ }^{37}$ Wijaya, 46.
}

${ }^{35}$ Wijaya, "Mulut," 46.

OKARA: Jurnal Bahasa dan Sastra, Vol. 15, No. 2, November 2021 
Putu Wijaya questions the government's act of capturing citizens by assaulting the government's belief system of "uniformity," with which the government's security and stability practice was based. He debates the state's concept of "abnormality": "Saudara-saudara sudah dikacaukan untuk membiasakan yang tidak normal" (You have been made to be commonplace with the abnormality) ${ }^{38}$ which is "keliru" (false). Here he challenges the administration by attesting that the rationale of the belief system is nothing.

Through the issue of consistency, Putu Wijaya speaks to the government's arrangement not to acknowledge any contrasts. He demonstrates that all individuals are not the same. Their contrasts ought to be resources, not perils to others. Everybody ought to be rise to, no matter what absconds they have.

Putu Wijaya, at that point, depicts the New Order's ceaseless exertion to deny its people's opportunity by uncovering a scene within the mouthless woman's travel after the administration makes a modern person out of the living one. She is changed into a lady with a mouth and uncommon abilities in speaking. She says a lot. Her talking turns into dread for her community. The change does not allow her to specify herself openly. Putu Wijaya suggests that nothing would be ideal if the administration abuses itself.
"Tangkap wanita yang kebanyakan mulut itu ..." "Memang. Memang susah tidak punya mulut, jadi kalau begini. Main gossip, memfitnah, membakarbakar, ayo cepat selamatkan dia!"

(Capture the gossipy woman,"... It's difficult not to have a mouth in the event that so, tattling, criticizing, inciting, capture her immediately!). ${ }^{39}$

The cite shows Putu Wijaya is concerned about the state's inner conflict in taking care of individuals' liberty. He dissents against the state's reluctance to grant add-up to flexibility to its individuals. He infers that the state is over-serious in this matter. He writes that the government gives a "caged freedom," freedom to be utilized within the hallway given by the government. Once it is resisted, opportunity can be taken back.

Putu Wijaya represents the New Order as an authoritarian regime that recognizes good individuals as those who comply with what they need. He indicates it from what the lady encounters after she gets her mouth. A year afterward, when she comes back, she is mouthless again. Once more, she has gone through another constrained operation.

In short, the story juxtaposes reality with non-reality. The story of "Mulut" portrays terror surrealistically. It satirically resounds the New Order government, which appreciated individuals' obedience rather than being out-spoken. The authority expected its public to agree with what the state had chosen, and dissent was not appreciated. Differently, this narrative portrays that quietness is also

${ }^{38}$ Wijaya, "Mulut," 47.

${ }^{39}$ Wijaya, "Mulut," 48. 
forbidden while fostering the issue of uniformity. Finally, the story compares the issue of abnormality against commonness.

Above all, the story represents the issues of gagging, intimidation, and being bereft of freedom, which are also evident in the works of some world writers, including Gabriel Garcia Márquez. ${ }^{40}$ The terror theme that Putu Wijaya employs in the stories will possibly inspire his younger generation of writers to write about such a practice in their works and encourage his readers to detest it. The use of terror as violence is his fictional way to remind them of human rights violations that have taken place in Indonesia and other countries. Such depiction has also been evident in the works of writers in countries such as Argentine,${ }^{41}$ Ireland, ${ }^{42}$ and Peru. ${ }^{43}$

\footnotetext{
${ }^{40}$ Gabriel Garcia Márquez in Cida S. Chase, "'La Violencia' and Political Violence in García Márquez's Short Fiction," The Journal of Popular Culture 22, no. 1 (1988): 73-82, https://doi.org/10.1111/j.00223840.1988.2201_73.x.

41 Robin Fiddian, "Niall H. D. Geraghty, The Polyphonic Machine: Capitalism, Political Violence, and Resistance in Contemporary Argentine Literature," Journal of Latin American Studies 52, no. 3 (2020): 673-75, https://doi.org/10.1017/S0022216X20000759.

42 Amy E. Martin, "The Dispossessed State: Narratives of Ownership in 19th Century Britain and Ireland; Human Encumbrances: Political Violence and the Great Irish Famine," Nineteenth-Century Contexts 35, no. 4 (2013): 435-42, https://doi.org/10.1080/08905495.2013.822693.

43 Jerónimo Ríos, "Narratives about Political Violence and Reconciliation in Peru," Latin American Perspectives 46, no. 5 (2019): 44-58 https://doi.org/10.1177/0094582X19856890.
}

\section{Conclusion}

Putu Wijaya's works, especially the three stories under detailed analysis, transform the terror issues to create psychological and social storylines. Although Putu Wijaya's "terror" themes do not deal with mass destruction or political attacks, they present something specific. The themes are helpful in picturing sociopolitically motivated state violence that terrorizes the nation. Although the themes are plotted in the lowest social realities and characterize marginalized people, they expose the oppressive acts practiced by specific individuals or groups within the government to execute their power or corrupt such power. The lines can be alternative readings from which readers can understand human rights violations written in Indonesian media.

The three stories indicate a few significant points: first, Putu Wijaya's grievances on Indonesian socio-political injustice; second, his concerns with freedom of expression, the right to life, and the right to assembly in ideology and practice; third, the elucidation of the facts that Indonesians still struggle for these fundamental rights; fourth, his urge on readers to question the practice of violence in this nation; fifth, his wills to show a type of disobedience to the situations caused by the state; and last, his attempt to create a connection between fiction and the government power, between story and political dynamics. 


\section{References}

Astuti, Tri Sakti Murti. "Aspek Sosial dalam Kumpulan Cerpen Protes Karya Putu Wijaya: Tinjauan Sosiologi Sastra." Bachelor Thesis, Universitas Muhammadiyah Surakarta, 2010.

Chase, Cida S. "'La Violencia' and Political Violence in García Márquez's Short Fiction." The Journal of Popular Culture 22, no. 1 (1988): 73-82.

https://doi.org/10.1111/j.00223840.1988.2201_73.x.

Collins, Elizabeth Fuller. "Indonesia: A Violent Culture?" Asian Survey 42, no. 4 (2002): 582-604. https://doi.org/10.1525/as.2002.42.4 .582 .

Dewanto, Nirwan. "Penutup." In Kado Istimewa Cerpen Pilihan Kompas, edited by Kenedi Nurhan. Jakarta: Harian Kompas, 1992.

Ferdinal. "Censorship, Resistance and Transformation in Modern Indonesian Literature." Mediterranean Journal of Social Sciences 4, no. 1 (2013): 269-72. https://doi.org/10.5901/mjss.2013.v4 n1p269.

Ferdinal. "Injustice: Revealing Human Rights Issues in Ali Akbar Navis's Short Fiction." European Journal of Interdisciplinary Studies 1, no. 1 (2015): 137-43. https://doi.org/10.26417/ejis.v1i1.p1 37-143.

Ferdinal. "Women's Rights and Colonization in the Short Story of The Jakarta Post." Vivid: Journal of Language and Literature 9, no. 1 (2020): $1-11$. https://doi.org/10.25077/vj.9.1.111.2020 .

Fiddian, Robin. "Niall H. D. Geraghty, The Polyphonic Machine: Capitalism, Political Violence, and Resistance in Contemporary Argentine Literature." Journal of Latin American Studies
52, no. 3 (2020): 673-75. https://doi.org/10.1017/S0022216X2 0000759.

Fletcher, Angus. Allegory: The Theory of Symbolic Mode. Ithaca and London: Cornell University Press, 1964.

Heriyati, Nungki, Riris K. Sarumpaet, and Christina T. Suprihatin. "Speaking Through Silence: Trauma in Literary Work." In Proceedings of the International Conference on Business, Economics, Social Science, and Humanities Humanities and Social Sciences Track (ICOBEST-HSS 2019). Bandung, Indonesia: Atlantis Press, 2020.

https://doi.org/10.2991/assehr.k.200 108.037 .

Herlambang, Wijaya. Kekerasan Budaya Pasca 1965: Bagaimana Orde Baru Melegitimasi Anti-Komunisme Melalui Sastra dan Film. Tangerang: Marjin Kiri, 2013.

Heryanto, Ariel. Identitas dan Kenikmatan: Politik Budaya Layar Indonesia. 2nd ed. Jakarta: Kepustakaan Populer Gramedia, 2018.

lyubenu, Edi AH. "Estetika Teror (Khas) Cerpen Koran." Surabaya Post, June 12, 2000.

Logsdon, Martha Gay. "Neighborhood Organization in Jakarta." Indonesia 18 (1974): 53-70. https://doi.org/10.2307/3350693.

Maier, Henk M. J. "Telling Tales, Cutting Throats the Guts of Putu Wijaya." In Roots of Violence in Indonesia, edited by Freek Colombijn and J. Thomas Cinblad, 63-79. Leiden: KITLV Press, 2020.

Martin, Amy E. "The Dispossessed State: Narratives of Ownership in 19th Century Britain and Ireland; Human Encumbrances: Political Violence and the Great Irish Famine." Nineteenth-Century Contexts 35, no. 4 (2013): 435-42. https://doi.org/10.1080/08905495.20 13.822693 . 
Nurhadi. "Kekerasan di Indonesia dalam Karya Sastra." Ibda': Jurnal Kajian Islam dan Budaya, no. 55 (2009): 111.

Rafferty, Ellen. "The New Tradition of Putu Wijaya." Indonesia 49 (1990): 10316. https://doi.org/10.2307/3351055.

Ríos, Jerónimo. "Narratives about Political Violence and Reconciliation in Peru." Latin American Perspectives 46, no. 5 (2019): 44-58. https://doi.org/10.1177/0094582X19 856890.

Sunarti. "Nilai Nilai Budaya dalam Novel Tiba Tiba Malam Karya Putu Wijaya: Tinjauan Semiotik." Bachelor Thesis, Universitas Muhammadiyah Surakarta, 2008. http://eprints.ums.ac.id/id/eprint/235 7.
Wahyuni, Dessy. "Pertarungan Jurnalisme dan Sastra dalam Menguak Kebenaran." Paradigma: Jurnal Kajian Budaya 9, no. 3 (2019): 23155.

https://doi.org/10.17510/paradigma. v9i3.325.

Wijaya, Putu. "Mulut." Horison: Majalah Sastra, October 1995.

Wijaya, Putu. "Rakyat." Horison: Majalah Sastra, October 1995.

Wijaya, Putu. "Sket." In Kado Istimewa: Cerpen Pilihan Kompas 1992, edited by Kenedi Nurhan. Jakarta: Harian Kompas, 1992.

Žižek, Slavoj. Violence. New York: Picador, 2008. 